\title{
PRINCIPLES OF SAMPLING IN EDUCATIONAL RESEARCH IN HIGHER EDUCATION
}

\author{
Andreas Ahrens \\ Department of Electrical Engineering and Computer Science, \\ Faculty of Engineering, Hochschule Wismar, University of Applied Sciences, Technology, \\ Business and Design, Germany \\ Jeḷena Zaščerinska \\ Centre for Education and Innovation Research, Latvia
}

\begin{abstract}
Innovation and creativity in European society are fostered via a dynamic and flexible European higher education based on the integration between education and research at all levels (Communiqué, 2009). The synergy between education and research is effeciently driven via educational research.Sampling as an element of the educational research has a two-fold role: sample size is inter-connected with statistical analysis of the data and generalisation. Against this background, little attention has been given to principles of sampling in educational research. The research question is as follows: what principles form sampling in educational research? The aim of the research is to analyse scientific literature and work out principles of sampling in educational research underpinning elaboration of a new research question for further studies in educational research. The present research involves a process of analysing the meaning of the key concept "principle". In the empirical study, explorative research was employed. Interpretive research paradigm was used. The empirical study involved six experts from different countries in February 2013 - July 2014. The findings of the research allow drawing the conclusions on the elaborated principles of sampling in educational research. Directions of further research are proposed.
\end{abstract}

Keywords: Educational Research, Higher Education, Interdisciplinary Research, Principle, Principles of Sampling, Sample, Sampling.

\section{Introduction}

In the decade up to 2020 European higher education has a vital contribution to make in realising a Europe of knowledge that is highly creative and innovative (Communiqué, 2009).

Innovation and creativity in European society are fostered via a dynamic and flexible European higher education based on the integration between education and research at all levels (Communiqué, 2009) as shown in Figure 1.

The synergy between education and research is effeciently driven via educational research. Educational research facilitates enrichment of such pedagogical and educational developments as organization of educational environment, curriculum design and implementation, enhancement of educational institution activities in terms of research, etc. in order to promote students' knowledge, competences and behavior aimed at ensuring new discoveries, innovations, etc. (Ahrens \& Zaščerinska, 2014a). Success in carryingout educational research is generated by a couple of strategies. For 
evidence based educational research, one of the strategies is focused on sample analysis (Mayring, 2007).

Education

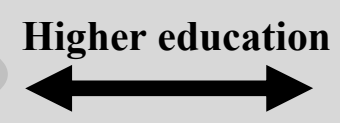

Research

Figure 1. The relationship between higher education, education and research

Analysis of scientific literature reveals that, on the one hand, a number of terms such as sample, sampling, scientific sample, statistical sampling, sampling scheme, sampling plan,sample design, sampling procedures, sample size, etc. exist, and, on the other hand, despite the differences in the terms, sampleremains the overall concept as manifested in Figure 2.

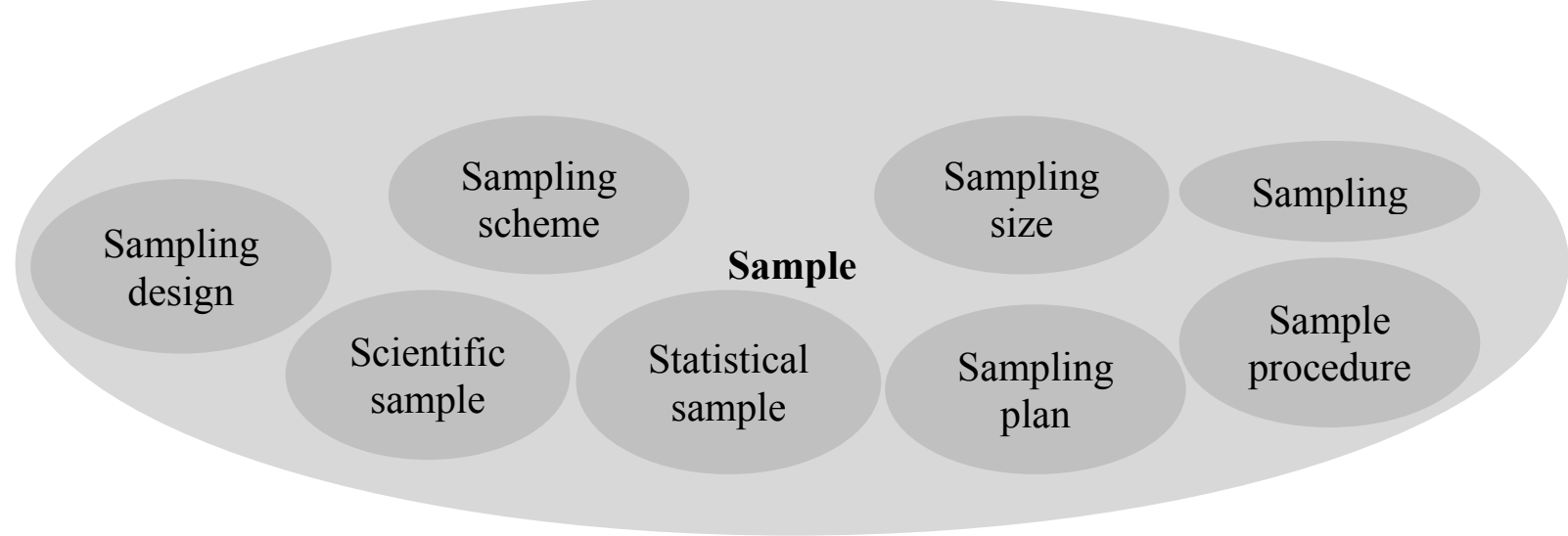

Figure 2. The relationship between the terms of sample

Within the present contribution, sampling focuses on obtaining a group of subjects who will be representative of the larger population or will provide specific information needed (McMillan, 1996). The goal is to select a sample that will adequately represent the population, so that what is described in the sample will also be true of the population (McMillan, 1996). It should be noted that, in educational research, the best procedure for selecting such a sample is to use probability sampling as non-probability sampling does not ensure the construction of a parameter for a population. Moreover, the primary distinction between the two domains is that the probability sampling study findings can be generalized to the target population while the non-probability sampling study findings can only be generalized to the institution where the sample was studied (Summers, 1991). The key characteristic of a probability sample is that each element in the population has a known probability of being included in the sample (Sweeney, 2013). The probability sampling procedures include simple 
random, systematic, stratified, and cluster (McMillan, 1996) as demonstrated in Figure 3.

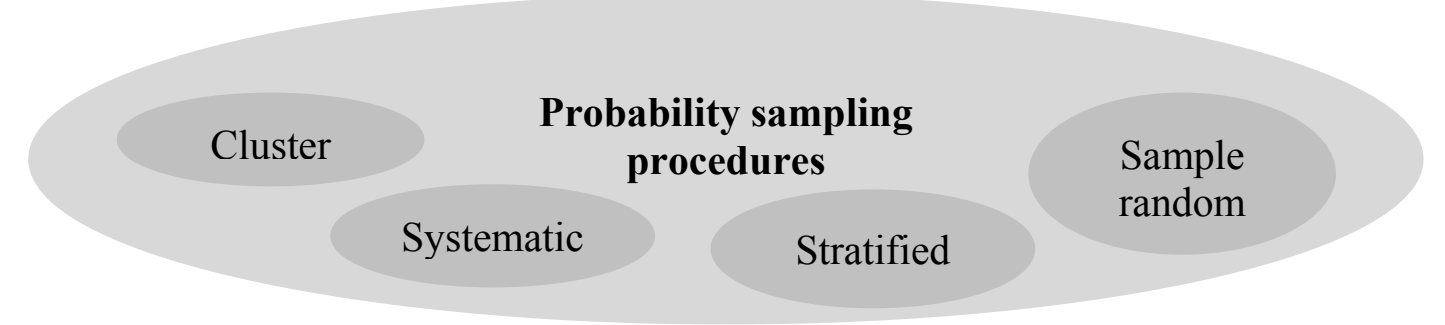

Figure 3. Probability sampling procedures

The process of sample selection has attracted a lot of research efforts in all the research fields:

- In farmer surveys, sampling methods range from the practical to the mathematical are focused on good practical points (Coe, 1996).

- In organizational research, the procedures for determining sample size for continuous and categorical variables have been described by use of Cochran's (1977) formulas (Bartlett et al., 2001).

- In psychological research, analysis of selection of sample size has contributed to the outline of three criteria of sample size (Kroplijs \& Raščevska, 2004).

- In management and economics research, the emphasis is put on analysis of factors influencing sample size (Kamau et al., 2012).

Hence, sampling has a two-fold role in research as depicted in Figure 4: sampling is inter-connected with

- $\quad$ statistical analysis of the data and

- generalisation or theory formulation.

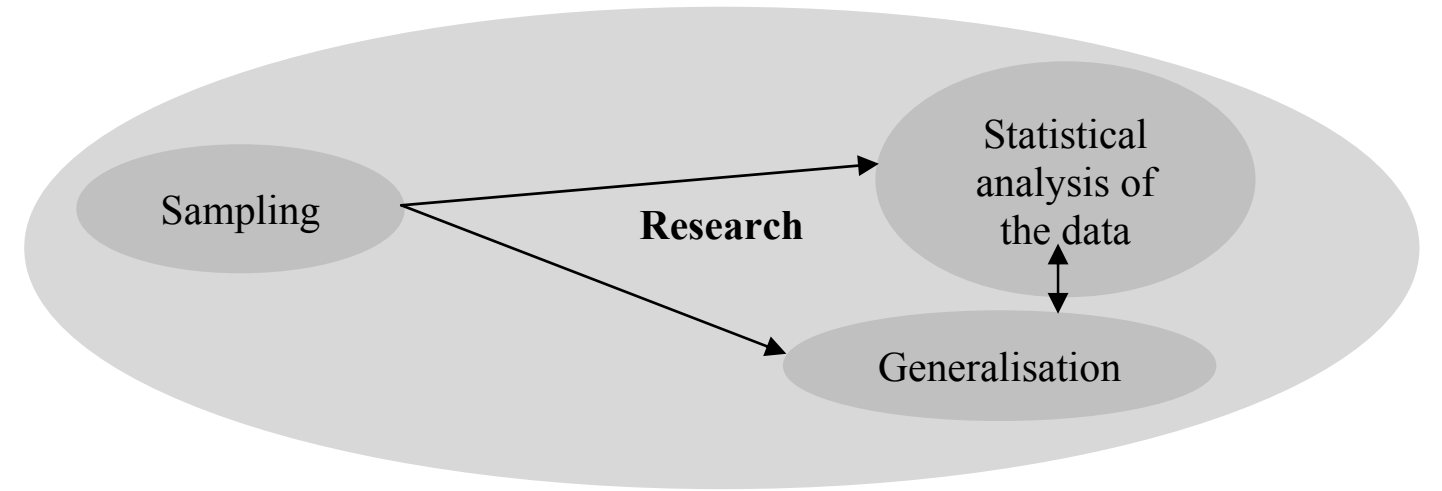

Figure 4. Relationship between sampling and statistical analysis of the data and generalization in research

In educational research, sampling has attracted a lot of research efforts, too. Traditionally, sampling refers to empirical studies of educational research as illustrated in Figure 5. 
Educational research
Empirical study

Sampling

Figure 5. Relationship between research, empirical studies and sampling in educational research

It should be noted that empirical studies are differentiated into quantitative, qualitative as well as hybrid/mixed studied as disclosed in Figure 6.

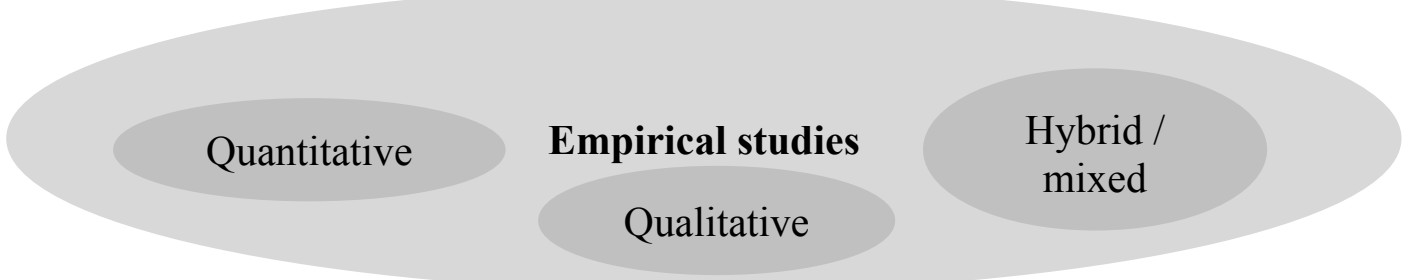

Figure 6. Types of empirical studies

In educational research, factors that influence sample size have been identified (Ahrens \& Zaščerinska, 2014a) as well as a framework for selecting sample size has been proposed (Ahrens \& Zaščerinska, 2014b). However, little attention has been given to the principles of sampling in educational research.

The research question is as follows: what principles form sampling in educational research?

The aim of the research is to analyse scientific literature and work out principles of sampling in educational research underpinning elaboration of a new research question for further studies in educational research.

The present research involves a process of analysing the meaning of the key concept principle. Moreover, the study demonstrates how the key concept is related to the idea of "principles of sampling". The study presents how the steps of the process are related: principle $\rightarrow$ principles of sampling in educational research $\rightarrow$ empirical study within a multicultural environment.

The methodological background of the present research is based on the System-Constructivist Theory. The System-Constructivist Theory is introduced as the New or Social Constructivism Pedagogical Theory. The SystemConstructivist Theory and, consequently, System-Constructivist Approach to learning introduced by Reich (Reich, 2005) emphasizes that human being's point of view depends on the subjective aspect (Maslo, 2007) as experience 
plays the central role in the knowledge construction process (Maslo, 2007). Therein, the subjective aspect of human being's point of view is applicable to the present research on principles of sampling in educational research.

The System-Constructivist Theory facilitates the application of interdisciplinary research within the present investigation as interdisciplinary research assists in synthesizing, connecting and blending ideas, data and information, methods, tools, concepts, and/or theories from two or more disciplines in order "to make whole" (Repko, 2012). Figure 7 adopted from Repko (Repko, 2012) presents how the process of interdisciplinary research is organized where ' $A$ ' means a scientific discipline, and ' $B$ ' - another scientific discipline.

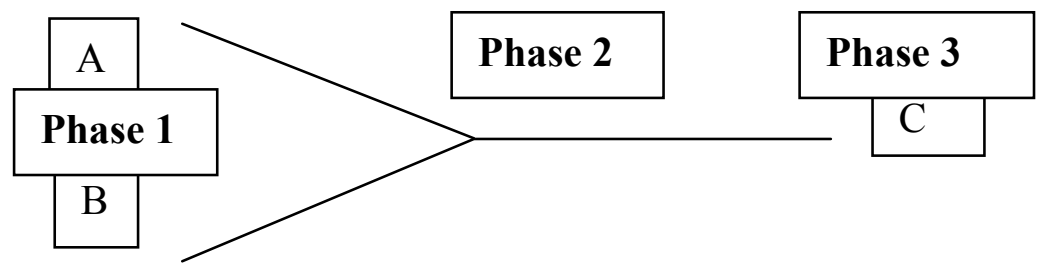

Figure 7. The process of interdisciplinary research by Repko (adopted from Repko, 2012)

It should be noted that the present research is not limited to only two scientific disciplines but is based on a number of scientific disciplines such as agriculture, pedagogy, management, economics, psychology, environment, etc.

\section{Theoretical Framework}

For the purposes of further theoretical analysis, it should be noted that in the present contribution education is part of pedagogy as displayed in Figure 8.

Pedagogy Education

Figure 8. Inter-relationship between pedagogy and education

In pedagogy and, consequently, in educational research, principle is identified as a certain viewpoint system and /or internal belief that determine person's attitude to the world, his/her behaviour's norms and actions (Belickis et al., 2000). Analysis of this definition of principle and complementing this principle definition formulated by Beļickis et al (Belickis et al., 2000) for pedagogical purposes with the words individual combination in regard to a researcher leads to such a newly determined definition of principle as an individual combination of beliefs and assumptions that determine researcher's attitude to the world, his/her behaviour's norms and actions or, in other words, sampling in educational research. Further on, complementing the principle 
definition formulated by Beļickis et al (Beļickis et al., 2000) for pedagogical purposes with the words shared combination in regard to a group of researchers leads to such a newly determined definition of principle as a shared combination of beliefs and assumptions that determine researchers' attitude to the world, their behaviour's norms and activities or, in other words, sampling in educational research.

Analysis of scientific literature allows structuring the principles of sampling in accordance with three types of empirical studies as delivered in Table 1.

Table 1. Principles of sampling in different types of empirical studies

\begin{tabular}{|c|c|c|}
\hline Quantitative studies & $\begin{array}{l}\text { Qualitative } \\
\text { studies }\end{array}$ & Hybrid / mixed studies \\
\hline $\begin{array}{l}\text { Principle } 1 \text { - be a difference between } \\
\text { the sample statistics and the true } \\
\text { population mean, which is attributable } \\
\text { to the selection of the units in the } \\
\text { sample. } \\
\text { Principle } 2 \text { - the greater the sample } \\
\text { size, the more accurate the estimate of } \\
\text { the true population mean. } \\
\text { Principle } 3 \text { - the greater the difference } \\
\text { in the variable under study in a } \\
\text { population for a givensample size, tile } \\
\text { greater the difference between the } \\
\text { sample statistics and the true } \\
\text { population mean (Kumar, 1996). }\end{array}$ & \multirow[t]{2}{*}{$\begin{array}{l}\text { "Accuracy" } \\
\text { (increase sample } \\
\text { size) with "cost" } \\
\text { (decrease sample } \\
\text { size), } \\
\text { heterogeneity } \\
\text { (Yount, 2006) }\end{array}$} & $\begin{array}{l}\text { The quantitative principle of } \\
\text { representativeness and the } \\
\text { qualitative principle of } \\
\text { appropriateness (Morse, } \\
\text { 1991) }\end{array}$ \\
\hline $\begin{array}{l}\text { Reducing bias and variation in bulk } \\
\text { sampling (Smith, 2008). }\end{array}$ & & $\begin{array}{l}\text { General principles: } \\
\text { representativity, } \\
\text { heterogeneity (Minkkinen, } \\
\text { 2008). }\end{array}$ \\
\hline
\end{tabular}

It should be noted that the paradigm in educational research shifts towards hybrid / mixed empirical studies as the approach of mixed methods provides more precise results: qualitative methods explain the differences, and quantitative methods reveal the amount of differences (Hunter \& Brewer, 2003). Therefore, only the principle of sampling in hybrid \& mixed empirical studies identified by Morse (Morse, 1991) and Minkkinen (Minkkinen, 2008) are considered for further analysis. Analysis of the scientific papers authored by Morse (Morse, 1991) and Minkkinen (Minkkinen, 2008) reveals that the principles determined by Morse (Morse, 1991) and Minkkinen (Minkkinen, 2008) seem to be a combination of quantitative and qualitative principles worked out before. Against this background, principle is a condition of activity (Belickis et al., 2000) or, in other words, sampling in educational research. A condition means a circumstance from which theimplementation of aprocess, processor activity depends (Belickis et al., 2000) or, in other words, sampling in 
educational research. In the present research sampling depends on the interrelationships between sample size and statistical analysis of the data, sample size and generalization (Ahrens \& Zaščerinska, 2014b). Therein, in the present research, conditions are regarded as the inter-relationships between sample size and statistical analysis of the data, sample size and generalization (Ahrens \& Zaščerinska, 2014b). The following inter-relationships between sample size and statistical analysis of the data, sample size and generalization (Ahrens \& Zaščerinska, 2014b) are highlighted:

- $\quad$ in the measurement phase, the parameters of measurement tools and scales are kept fixed when used by sample's further components or elements,

- $\quad$ in the data processing phase, the tests carried out on a given set of data allow extracting the requiredinformation in an appropriate form such as diagrams, reports, or tables,

- in the statistical analysis phase, the information extracted from the obtained data processing ensures a possibility to make conclusions and generalisations.

- $\quad$ in the analysis phase, sample's further components or elements do not change conclusions or generalisations drawn from the obtained data (Kroplijs, Raščevska, 2004).

These findings on the inter-relationships between sample size and statistical analysis of the data, sample size and generalization (Ahrens \& Zaščerinska, 2014b) serve as a source of principles of sampling in educational research indicated in Table 2.

Table 2. Principles of sampling in educational research

\begin{tabular}{|c|c|}
\hline Circumstances & Principle of sampling \\
\hline $\begin{array}{l}\text { In the measurement phase, the parameters of } \\
\text { measurement tools and scales are kept fixed when } \\
\text { used by sample's further components or elements }\end{array}$ & \multirow[b]{2}{*}{ Principle of sample appropriateness } \\
\hline $\begin{array}{l}\text { In the data processing phase, the tests carried out on } \\
\text { a given set of data allow extracting the } \\
\text { requiredinformation in an appropriate form such as } \\
\text { diagrams, reports, or tables }\end{array}$ & \\
\hline $\begin{array}{l}\text { In the statistical analysis phase, the information } \\
\text { extracted from the obtained data processing ensures a } \\
\text { possibility to make conclusions and generalisations }\end{array}$ & Principle of sample sufficiency \\
\hline $\begin{array}{l}\text { In the analysis phase, sample's further components } \\
\text { or elements do not change conclusions or } \\
\text { generalisations drawn from the obtained data } \\
\text { (Kroplijs, Raščevska, 2004) }\end{array}$ & Principle of sample confidence \\
\hline
\end{tabular}




\section{Empirical Results}

The present part of the contribution demonstrates the design of the empirical research, survey results and findings of the research.

The design of the present empirical research comprises the purpose and question, sample and methodology of the present empirical study.

The empirical study was aimed at evaluating the principles of sampling in educational research. The empirical research's question was as follows: What is expert evaluation of the principles of sampling in educational research?

The present empirical study involved six experts from different countries in February 2013 - July 2014. All the respondents have been awarded PhD Degree in different scientific disciplines. As the respondents with different cultural backgrounds and diverse educational approaches were chosen, the sample was multicultural. Thus, the group (age, field of study and work, mother tongue, etc.) is heterogeneous. The sample of six experts involved two researchers in the field of educational research, Educational Research Association, „Freie Universität” (Free University), Berlin, Germany, a researcher in the field of educational research, Latvia University of Agriculture, Jelgava, Latvia, a researcher in the field of applied research in education, CAH -Vilentum University of Applied Sciences, Dronten, the Netherlands, two researchers in the field of e-business and telecommunications, Vienna University of Technology, Vienna, Austria. In order to save the information of the present research confidential, the respondents' names and surnames were coded as follows: two researchers from Germany were given the codes of E1 (Expert 1) and E2 (Expert 2), a researcher from Latvia was pointed as E3 (Expert 3), a researcher from the Netherlands was considered as E4 (Expert 4), and two researchers from Austria were indicated as E5 (Expert 5) and E6 (Expert 6).

Interpretive research paradigm was used in the present empirical study. The interpretive paradigm aims to understand other cultures, from the inside through the use of ethnographic methods such as informal interviewing, participant observation and establishment of ethically sound relationships (Taylor \& Medina, 2013). Interpretive paradigm is characterized by the researchers' practical interest in the research question (Cohen et al., 2003).

Exploratory research was employed in the empirical study (Phillips, 2006). Exploratory research is aimed at generating new questions and hypothesis (Phillips, 2006). The exploratory methodology proceeds from exploration in Phase 1 through analysis in Phase 2 to hypothesis development in Phase 3.

The qualitatively oriented empirical study allows the construction of only few cases (Mayring, 2004). Moreover, the cases themselves are not of interest, only the conclusions and transfers we can draw from these respondents (Flyvbjerg, 2006). Selecting the cases for the case study comprises use of information-oriented sampling, as opposed to random sampling (Flyvbjerg, 2006). This is because an average case is often not the richest in information. In 
addition, it is often more important to clarify the deeper causes behind a given problem and its consequences than to describe the symptoms of the problem and how frequently they occur (Flyvbjerg, 2006). Random samples emphasizing representativeness will seldom be able to produce this kind of insight; it is more appropriate to select some few cases chosen for their validity. Further on, the choice of experts was based on two criteria as depicted in Figure 9: recognized knowledge in the research topic and absence of conflict of interests (Lopez \& Salmeron, 2011).

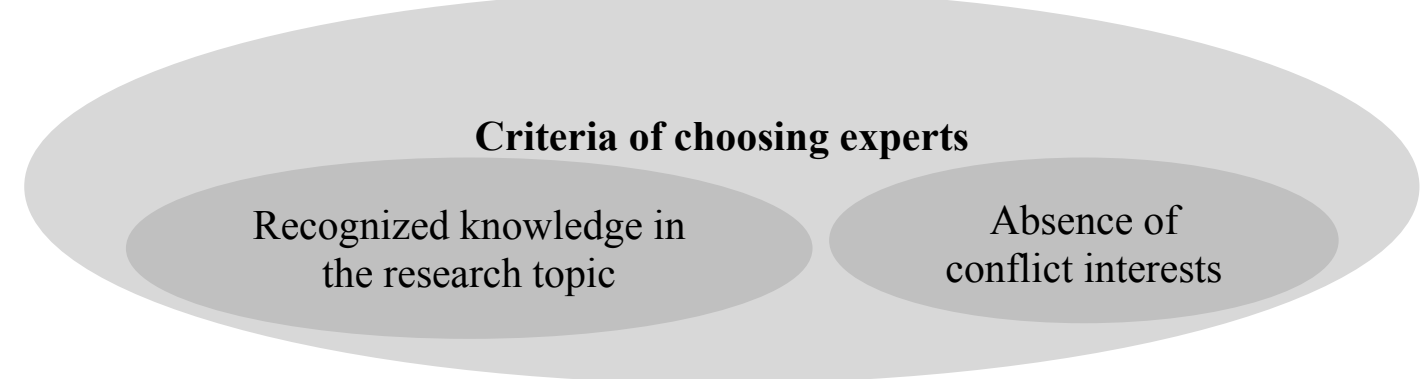

Figure 9. Criteria of choosing experts

The number of experts depends on the heterogeneity of the expert group: the greater the heterogeneity of the group, the fewer the number of experts (Okoli \& Pawlovski, 2004). Thus, six is a good number of experts for the study (Lopez \& Salmeron, 2011). There in, the non-structured interviews comprised six experts who were researchers from different countries. It should be noted that all the researchers were professors in different scientific disciplines. All the six researchers had decisively contributed to their fields of research. All the six researchers had received extensive research experience.

In order to evaluate the principles of sampling in educational research, nonstructured inteviews were carried out. Non-structured interviews with experts were conducted in order to search for the main categories of the research field (Kroplijs \& Raščevka, 2004) or, in other words, evaluation of the principles of sampling in educational research. Expert 1 thanked the authors for the interesting abstract submitted to the conference where Expert 1 was acting as a reviewer. Expert 2 underlined that the authors had tried to summarize a study and identify the main characteristics of this study. Expert 3 was interested in the continuation of the study. Expert 4 assumed that the factors play a key role in forming the sample size in educational research. Expert 5 stressed the use of the research results in other scientific disciplines. Expert 6 emphasized that the contribution submitted to the conference where Expert 6 was acting as a reviewer had been well done. Summarizing content analysis (Mayring, 2004) of the data reveals that experts positively evaluated the principles of sampling in educational research. 


\section{SOCIETY. INTEGRATION. EDUCATION. Volume I}

\section{Conclusions}

The empirical findings of the research allow drawing the conclusions on experts' positive evaluation of the principles of sampling in educational research.

The following research question has been formulated: what is the methodology of sampling in educational research?

The present research has limitations. The inter-connections between principle, conditions, circumstances, sample size and statistical analysis of the data, sample size and generalizationhave been set. Another limitation is the empirical study conducted by involving the experts only. Therein, the results of the study cannot be representative for the whole area. Nevertheless, the results of the research - the definitions of principle and conditions in educational research as well as the principles of sampling in educational research- may be used as a basis of analysis of expert evaluation of the principles of sampling in educational research in other institutions. If the results of other institutions had been available for analysis, different results could have been attained. There is a possibility to continue the study.

Further research tends to focus on empirical studies to be carried out in other institutions. The search for relevant methods for evaluation of the principles of sampling in educational research is proposed. And a comparative research of different countries could be carried out, too.

\section{References}

Ahrens, A., Zaščerinska, J. (2014a). Factors that Influence Sample Size in Educational Research. 2014 ATEE Spring University proceedings Changing Education in a Changing Society, pp. 19-32. Published by Klaipeda University, Lithuania.

Ahrens, A., Zaščerinska, J. (2014b). A Framework for Selecting Sampe Size in Educational Research on e-Business Application. Mohammad S. Obaidat, Andreas Holzinger, Marten van Sinderen and Peter Dolog (Eds), In Proceedings of ICE-B 2014 11th International Conference on E-Business, Vienna, Austria, 28-30 August 2014, pp. 3138. Publisher: SciTePress - Science and Technology Publications. Printed in Portugal.

Bartlett, J.E., Kotrlik J.W., Higgins, C.C. (2001). Organizational Research: Determining Appropriate Sample Size in Survey Research. Information Technology, Learning, and Performance Journal, Vol. 19, No. 1, 43-50. Spring 2001.

Beļickis, I., Blūma, D., Koķe, T., Markus, D., Skujiņa, V. (vad.), Šalme, A. (2000). Pedagogijas terminu skaidrojošā vārdnīca. Termini latviešu, anglu, vācu, krievu valodā. Rīga: "Zvaigzne ABC".

Coe, R. (1996). Sampling Size Determination in Farmer Surveys. ICRAF Research Support Unit Technical Note No 4. ICRAF World Agroforestry Centre Nairobi, Kenya. 11 pp.

Cohen, L., Manion, L., Morrsion, K. (2003). Research Methods in Education. London and New York: Routledge/Falmer Taylor \& Francis Group.

Flyvbjerg, B. (2006). Five Misunderstandings About Case-Study Research. Qualitative Inquiry, 12(2), 219-245, (2006).

Hunter, A., Brewer, J. (2003). Multimethod Research in Sociology. In: Tashakkori, A., Teddlie, C. (Eds). Handbook of Mixed Methods in Social \& Behavioral Research, p. 
577-593. London, New Delhi: Sage Publications, International Educational \& Professional Publisher. Thousand Oaks.

Kamau, Guandaru, C., Kariuki, Nduati, S. (2012). Factors Influencing Sample Size for Internal Audit Evidence Collection in the Public Sector in Kenya. International Journal of Advances in Management and Economics. Mar.-April. 2012 | Vol.1 | Issue 2|42-49.

Kroplijs, A., Raščevska, M. (2004). Kvalitatīvās pētniecības metodes sociālajās zinātnēs. Rīga: RaKa.

Kumar R (1996). Research Methodology: A Step-by-Step Guide for Beginners. Sage Publications, London.

Lopez, C., Salmeron, J. (2011). A Framework for Classifying Risks in ERP Maintenance Projects. Proceedings of International Conference one-Business (ICE-B 2011), July 1821 2011, Seville, Spain,201-204. Publisher: SciTePress - Science and Technology Publications.

Maslo, E. (2007). Transformative Learning Space for Life-Long Foreign Languages Learning. In International Nordic-Baltic Region Conference of FIPLV Innovations in Language Teaching and Learning in the Multicultural Context, 38-46, Rīga: SIA „Izglītības solii”.

Mayring, P. (2004). Qualitative Content Analysis. In U. Flick, E. Von Kardoff and I. Steinke (Eds). A Companion to Qualitative Research, pp. 266-269. SAGE, UK, Glasgow.

Mayring, Philip (2007). On Generalization in Qualitatively Oriented Research. Forum Qualitative Sozialforschung /Forum: Qualitative Social Research, 8(3), Art. 26, 1-8.

McMIllan, J.H. (1996). Educational Research Fundamentals for the Consumer. Second Edition. Virginia Commonwealth University, HarperCollins College Publishers.

Minkkinen, P. (2008). Theory of Sampling: General principles for sampling heterogeneous materials. Paper presented at Reliable Data for Waste Management September 25-26, 2008, Vienna, Austria.

Morse, J.M. (1991). Strategies for sampling. In: Morse J.M. ed., Qualitative Nursing Research: A Contemporary Dialogue, pp. 127-145. Sage, Newbury Park, California.

Okoli, C., Pawlovski, S. (2004). The Delphi Method as a Research Tool: an example, design considerations and applications. Information and Management, 42(1), 15-29, (2004).

Phillips, D. (2006). Comparative Education: method. Research in Comparative and International Education, Volume 1, Number 4, 304-319, (2006).

Reich, K. (2005). Systemisch-konstruktivistische Pädagogik. Weinheim u.a., Beltz.

Repko, A. (2012). Interdisciplinary Research Process and Theory Second Edition. SAGE.

Smith, P. L. (2008). An Introduction to General Sampling Principles: Reducing Bias and Variation in Bulk Sampling. Journal of GXP Compliance Vol. 12, Issue 4, Jul 2008, 6065 .

Summers, S. (1991)Selecting the sample for a research study. J Post Anesth Nurs. Oct;6(5):355-8.

Sweeney, D. (2013). Statistics: The Normal Distribution. In Encyclopcedia Britannica.

Taylor, P.C., \& Medina, M.N.D. (2013). Educational Research Paradigms: From Positivismto Multiparadigmatic. The Journal of Meaning-Centered Education. Volume 1, Article 2.

The Bologna Process 2020 - The European Higher Education Area in the new decade. (2009). Communiqué of the Conference of European Ministers Responsible for Higher Education, Leuven and Louvain-la-Neuve, 28-29 April 2009.

Yount, W.R. (2006). Research Design and Statistical Analysis for Christian Ministry. Publisher: Dr. Rick Yount. 